\title{
OVERHEAD TRAVELLING CRANE CONSTRUCTION DEFLECTION MEASUREMENTS WITH TELEMATIC APPROACH
}

\author{
Pawel Hyla \\ AGH University of Science and Technology \\ Faculty of Mechanical Engineering and Robotics \\ Mickiewicza Av. 30, Krakow, Poland \\ e-mail:hyla@agh.edu.pl
}

\begin{abstract}
Transport has always been a fundamental impulse for the development of civilization. Issues related to the regularity of operation of technical systems, in the last decade have become important issues being considered from both the point of view, as well as economics. Today the major threat in the operational reliability constitutes intensification of the machine and equipment use leading to excessive degradation. In automated manufacturing processes where the material handling operations are realized by the cranes, the safety as both devices and operating people constitute important factor. The main purpose of the article was focused on the set of issues including the material handling devices (MHD) reliability shaping problem especially presents work in progress towards development the MHD condition assessment system with using telematic approach. In the article author, special care was enclosed to MHD devices with strength human factor interaction and relatively large construction, so the overhead travelling crane was chose. The object of the statement constitutes an attempt of collecting the knowledge concerning a possibility of use modern measurement systems to monitoring crane bridge deflection. All tests and considerations were conducted on the double girder overhead travelling crane with hosting capability $1000 \mathrm{~kg}$ and bridge span $8000 \mathrm{~mm}$.
\end{abstract}

Keywords: crane bridge deflection, total station, telematics

\section{Introduction}

Dynamic and static tests of material handling devices constructions usually are carried out in order to confirm design assumptions or more often as number of diagnostic tests to ensure feature-working conditions of the tested device. The described diagnostic tests are particularly related with specialized group of technological transport equipment called overhead travelling cranes (OTC) [1]. An overhead crane, commonly called a crane or bridge crane is a type of crane often found in industrial environments. An overhead crane consists of parallel runways with a traveling bridge spanning the gap. A hoist the main lifting component of a crane can travels along the bridge. Unlike mobile or special construction cranes, overhead cranes are typically used for either manufacturing or maintenance applications, where efficiency or downtimes are critical factors $[1,2]$. Periodic control and monitoring the condition the crane main parts like girder and bridge on the base critical geometrical parameters measure allows to ensure the continuity of the device exploitation, with simultaneous increasing its operational lifetime and the safety of use. In the last decade, the development of new technologies in measurements techniques [3], especially in measure vertical and horizontal angles and the point-to-point distance measure made great progress [4]. Application of these measurement techniques especially in relation to OTC device to measure geometry parameters is very helpful. However, so far it was possible measure crane geometry only when the device was stopped. With use modern telematics approach the cranes girder and bridge deflection can be inspected during their normal work period $[5,6]$, what minimize the losses associated with OTC downtime. The possibility of making measurements during the crane movement can be an invaluable help in finding reasons for its improper exploitation such as uneven expenditure of the wheels and rails or others. In mechanical 
engineering use until now optical-mechanical, measuring instruments, which have been used for many years [7], begin to give way to modern electronic instruments, including primarily electronic tachymeters [5]. A total station (TS) or total station theodolite (TST) is a device linking electronic and optical features in one instrument used mainly for surveying and building construction. It is an electronic transit theodolite integrated with electronic distance measurement (EDM) feature to measure both vertical and horizontal angles and the slope distance from the instrument to a particular point. The on-board built it computer allows to collect data and perform triangulation calculations often in the real time mode. Currently, geodetic electronic instruments (GEI) allow for high accuracy of measurements, and their standard and application software together with rich IT equipment enable automation of stages or entire processes of acquiring, processing, storing, and sharing information in any numerical or graphic form. In this article, special care was enclosed to OTC device.

The object of the statement constitutes an attempt of collecting the knowledge concerning a possibility of use a modern GEI device measure crane bridge deflection. All tests and considerations were conducted on the double girder overhead travelling crane with hosting capability $1000 \mathrm{~kg}$ and bridge span $8 \mathrm{~m}$.

\section{The crane bridge deflection measurement - the review}

In many cases, the condition for the reliability of the operation of transport systems, including primarily cranes (overhead cranes, gantry cranes, etc.) is to maintain sufficient stiffness and thus to prevent excessive deformation. In the vast majority of cases, the stiffness condition is automatically met if the nominal stresses do not exceed the admissible stresses. In this cases is enough to perform a strength calculation for the allowable stress, but it is not necessary to make calculations for acceptable deformations. However, there are cases when despite meeting the conditions resulting from calculations for allowable stresses is not possible because the permissible loads are not determined by the permissible stresses but by the deformations involved with construction displacement. In terms of the construction of cranes, which are cranes, the boundary conditions specifying the maximum deflection distance of crane girders, caused by a load equal to $120 \%$ of the nominal lifting capacity, with the most unfavourable location of the winch [6]. The maximum girders deflection for variety type of cranes cannot exceed the following values:

- for manually operated cranes $-L_{m} / 400$,

- for single-girder cranes with electric drive $-L_{m} / 500$,

- for double-girder cranes with electric drive $-L_{m} / 600$,

- for sub-runners of monorail hoists $-L_{m} / 400$.

\subsection{Girder deflection line - considerations}

The crane girder deflection can be determined from the curvature of the deformed beam axis from so-called beam deflection equation, which has a form (1):

$$
E I w^{\prime \prime}= \pm M .
$$

Based on formula (1) and Fig. 1 is possible to identify the following types of the girders deflection and derivation math formula to the maximum deflection (7):

$f_{a}$ - deflection at the point where the load is applied,

$f_{m}$ - deflection of the girders centre,

$f$ - the absolute greatest deflection.

Determination of reaction force in point $\mathrm{A}$ and $\mathrm{B}$ on the base Fig. 1:

$$
R_{a}=\frac{P \cdot b}{l} \quad \text { and } \quad R_{b}=\frac{P \cdot a}{l} .
$$



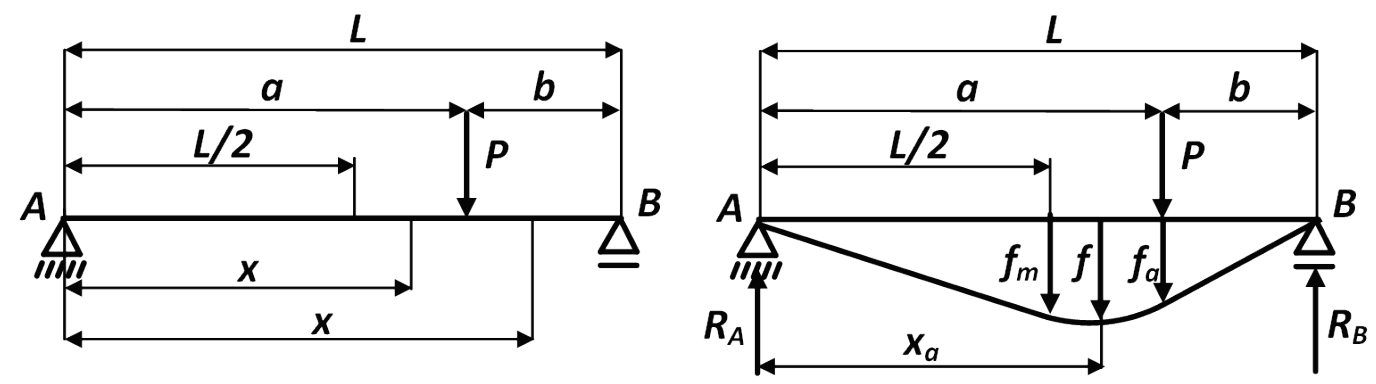

Fig. 1. Boundary condition in the crane girder deflection estimation

where:

$R_{a}$ - reaction force of girder beam in point $\mathrm{A}$,

$R_{b}$ - reaction force of girder beam in point $\mathrm{B}$,

$P \quad$ - test force (from the test load),

$a, b$-distance between point $\mathrm{A}$ or $\mathrm{B}$ and the point of applied test force,

$l \quad$ - girder length,

girder moments equation:

$$
\text { for } x \leq a \quad M_{x}=\frac{P \cdot b \cdot x}{l} \text { and for } x \geq a \quad M_{x}=\frac{P \cdot a \cdot(l-x)}{l},
$$

there are two options:

$$
x \leq a \Rightarrow y=\frac{P \cdot b}{6 \cdot E I} \cdot \frac{x}{l} \cdot\left(l^{2}-b^{2}-x^{2}\right), x \geq a \Rightarrow y=\frac{P \cdot a}{6 \cdot E I} \cdot \frac{l-x}{l} \cdot\left[l^{2}-a^{2}-(l-x)^{2}\right],
$$

where:

$E$ - Young's modulus (for the steel: $2.09-2.10 \times 10^{5} \mathrm{MPa}$ ),

$I$ - girder moment of inertia,

$E I$ - bending stiffness of the girder,

thereby:

$$
f=\frac{P \cdot b}{9 \cdot \sqrt{3} \cdot l \cdot E I} \cdot \sqrt{\left(l^{2}-b^{2}\right)^{3}} .
$$

Therefore, it turns out that for a beam supported with force concentrated anywhere, the largest deflection lies in the range (6):

$$
\frac{1}{2} \leq x_{e} \leq \frac{1}{\sqrt{3}}
$$

Then, the greatest deflection is not much different from the deflection of the centre point of the beam. Usually this difference does not exceed $2.5 \%$, so it is a possible to consider that the deflection of the girder centre $\left(f_{m}\right)$ is the same as the absolute greatest deflection $(f)$. Among others for this reason, for the overhead travelling crane girder deflection is measured in the middle accepting the formula (7).

$$
f \cong f_{m}=\frac{P \cdot b}{48 \cdot E I} \cdot\left(3 \cdot l^{2}-4 \cdot b^{2}\right) \sqrt{\left(l^{2}-b^{2}\right)^{3}} .
$$

Taking into account some amendments related with (7) it is possible to determine math formula for deflection at the point where the load is applied $\left(f_{a}\right)$.

$$
f_{a}=\frac{P \cdot a^{2} \cdot b^{2}}{3 \cdot l \cdot E I} .
$$




\section{Methodology of crane girder deflection measurement}

This article describes a various methodology and techniques in crane girder defection measure. As well as old school and modern approach were conducted on the double girder overhead travelling crane localized in AGH University of Science and Technology in Krakow (Fig. 2).
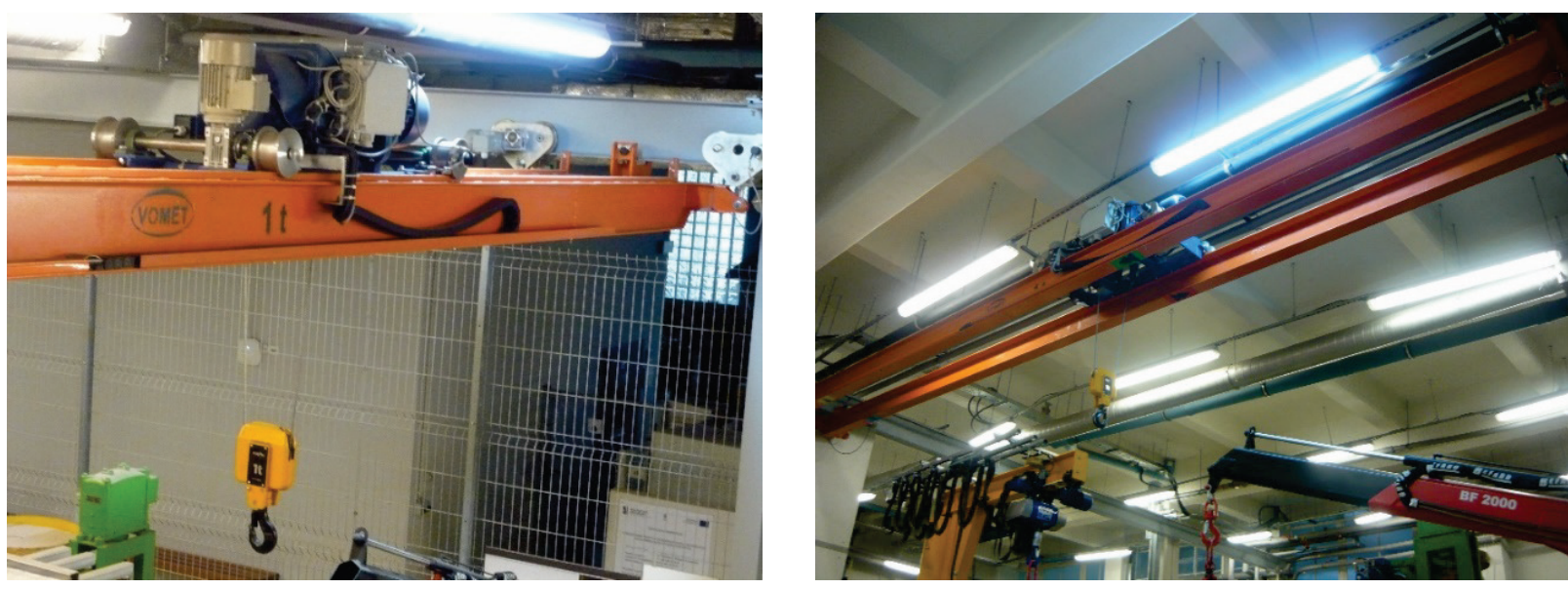

Fig. 2. Double girder overhead travelling crane with hosting capability $1000 \mathrm{~kg}$ (AGH University of Science and Technology in Krakow)

Tab. 2. Double girder overhead travelling crane (Fig. 2) - specification

\begin{tabular}{|l|l|}
\hline Crane type & double-girder structure with rope winch, capacity $1000 \mathrm{~kg}$ \\
\hline Crane bridge span & $8 \mathrm{~m}$ \\
\hline Maximum lift height & Max. lift height: $3.5 \mathrm{~m}$ \\
\hline Lifting speed & Lifting speed: two-speed (maximum speed up to $10 \mathrm{~m} / \mathrm{min}$ ), \\
\hline Winch drive speed & Winch drive speed: two speed available - adjustable via the inverter \\
\hline Gantry bridge speed & Gantry bridge speed: two-speed - adjustable via the inverter \\
\hline Control type & Radio (slave) control with a cable cassette (master) \\
\hline Power supply & $400 \mathrm{~V}, 50 \mathrm{~Hz}$ \\
\hline Work intensity group & FEM $2 \mathrm{~m} / \mathrm{M} 5$ \\
\hline Work rate & $60 \% \mathrm{ED}$ \\
\hline Number of switching cycles & $360 \mathrm{c} / \mathrm{h}$ \\
\hline
\end{tabular}

\subsection{Geodetic method with level wand levelling staff use}

A level is an optical instrument used to establish or verify points in the same horizontal plane in a process known as levelling, and is used in conjunction with a levelling staff to establish the relative heights levels of objects or marks. Geometric levelling in crane girder deflection [9, 10] measurement is a method consist on measuring the difference in height between two arbitrary chosen points before and after lifting the test load with use a target axis of the leveller and vertically aligned levelling rods [9] usually suspended in the following points (Fig. 3):

A - girder start point,

$\mathrm{B}$ - girder middle point (centre of gravity),

$\mathrm{C}$ - girder end point.

Table 2. presents the obtained results of the crane girder deflection obtained in several series of measurements by technique presented in Fig. 3. The measurements were carried out on the device presented in the Fig. 2. The laser rangefinder was also used in the measurements for experiment validate. The deflection of the bridge has always been measured at point B (Fig. 3) at different 
positions of the trolley: $i$ - crane winch at the edge of the bridge without load, $i i$ - crane winch in the middle of the bridge without the load, iii - crane winch in the middle of the bridge with maximum load $(1000 \mathrm{~kg}), i v$ - crane winch in the centre of the bridge without load and $v$ - crane winch at the edge of the bridge without load [9].
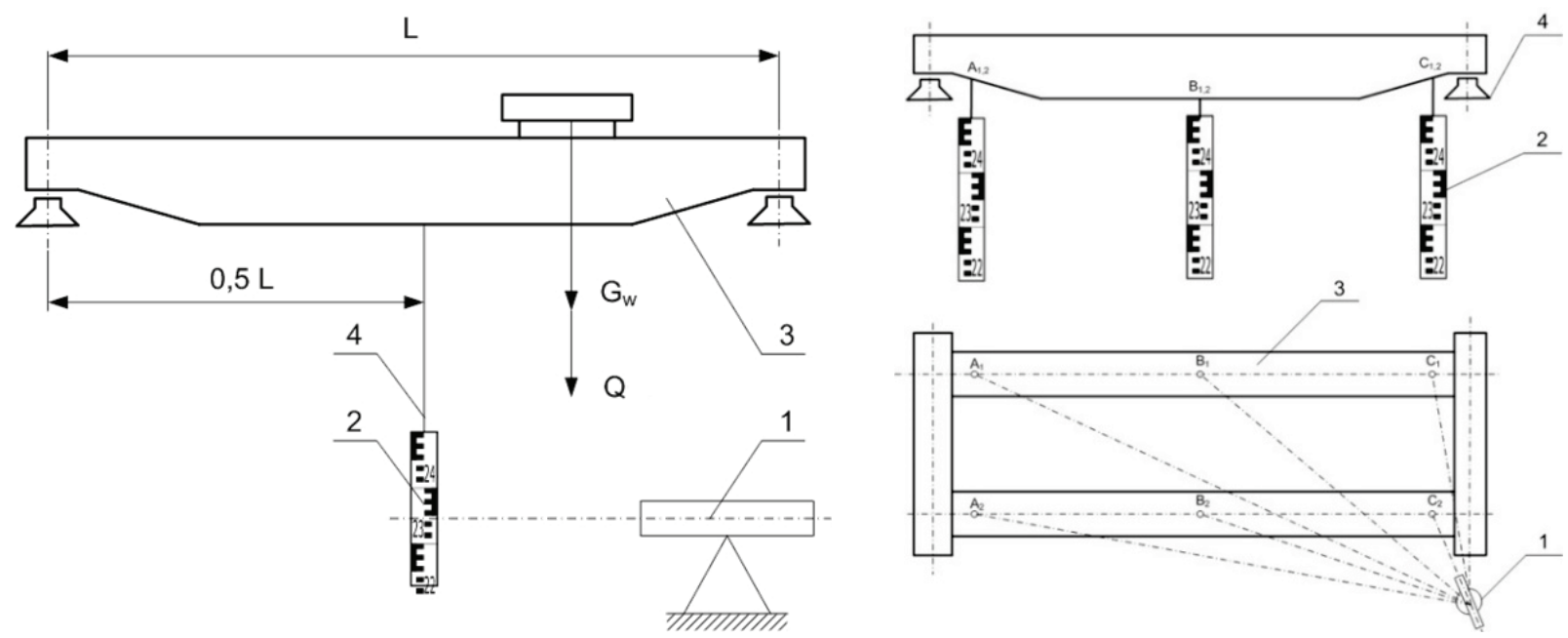

Fig. 3. Crane girder deflection measurement scheme with level use. In the left picture (front view): 1 -level

2 - levelling rod, 3 -crane girder, 4 -inextensible cord, $L$-girder length, $Q$-test load, $G_{w}$-load from the winch In the right picture: 1 -level position from top plane, 2 - levelling rods in point $A, B$ and $C, 4$-crane runway

Tab. 2. Crane girder deflection measured by level and laser range finder

\begin{tabular}{|c|c|c|c|c|}
\hline \multirow{3}{*}{$\begin{array}{c}\text { Crane } \\
\text { trolley } \\
\text { position }\end{array}$} & \multicolumn{4}{|c|}{ Measured value [mm] } \\
\cline { 2 - 5 } & $\begin{array}{c}\text { Level } \\
\text { (model: libell leveler NI 021 A) }\end{array}$ & \multicolumn{2}{c|}{$\begin{array}{c}\text { Laser range finder } \\
\text { (model: einhell BT-LEM40) }\end{array}$} \\
\cline { 2 - 5 } & $\begin{array}{c}\text { value read from } \\
\text { levelling staff }\end{array}$ & $\begin{array}{c}\text { girder deflection } \\
\text { (calculated) }\end{array}$ & absolute value & $\begin{array}{c}\text { girder deflection } \\
\text { (calculated) }\end{array}$ \\
\hline$i$ & $620 \pm 1.0$ & $0 \pm 1.0$ & $3711 \pm 1.5$ & $0 \pm 1.5$ \\
\hline$i i$ & $622 \pm 1.0$ & $0 \pm 1.0$ & $3711 \pm 1.5$ & $0 \pm 1.5$ \\
\hline$i i i$ & $630 \pm 1.0$ & $11 \pm 1.0$ & $3700 \pm 1.5$ & $11 \pm 1.5$ \\
\hline$i v$ & $622 \pm 1.0$ & $1 \pm 1.0$ & $3710 \pm 1.5$ & $1 \pm 1.5$ \\
\hline$v$ & $620 \pm 1.0$ & $1 \pm 1.0$ & $3710 \pm 1.5$ & \\
\hline
\end{tabular}

\subsection{Geodetic method with tachometer station use}

The girder deflection of the overhead travelling crane (Fig. 2) was measured with the use the Trimble S8 HP tachymetric station, whose most important parameters influencing the accuracy of measurement are summarized in Tab. 3. This is one of the most precise devices of this type available for the engineers and used in works related to precise geometric measurements and calculation.

\subsubsection{The experiment procedure and measurements}

The position of the instrument was located approximately at a distance of about $5.7 \mathrm{~m}$ from the crane bridge, more or less in the middle of its span. The tachymetric station was positioned on a standard geodetic tripod. The most necessary thing in the experiment was to mount a prism reflecting the laser beam from the tachymeter. There was used precision Nestle prism KTR1N PRO GPR1-SE of type with a special magnetic holder. The prism was installed on the crane trolley (Fig. 4). 
Tab. 3. Technical data of the Trimble S8 HP tachometric station

\begin{tabular}{|l|c|}
\hline \multicolumn{1}{|c|}{ Technical parameters of Trimble S8 HP } & Accuracy: \\
\hline Angle measurement accuracy (standard deviation according to DIN 18723 & $1 \mathrm{"} / 3 \mathrm{cc}$ \\
\hline Angle reading (the smallest value) & $0.1 \mathrm{l} / 0.1 \mathrm{cc}$ \\
\hline Distance measurement (RMSE accuracy) & $1 \mathrm{~mm}+1 \mathrm{ppm}$ \\
\hline Standard deviation according z ISO17123-4 & $0.8 \mathrm{~mm}+1 \mathrm{ppm}$ \\
\hline Tracking & $5 \mathrm{~mm}+2 \mathrm{ppm}$ \\
\hline Mirrorless standard measurement & $3 \mathrm{~mm}+2 \mathrm{ppm}$ \\
\hline \multicolumn{2}{|c|}{ Technical parameters of the laser range finder } \\
\hline Light source & Laser diode: $660 \mathrm{~nm}$ \\
\hline For measurements with the Prism & First class laser \\
\hline For measurements without the Prism & Second class laser \\
\hline
\end{tabular}

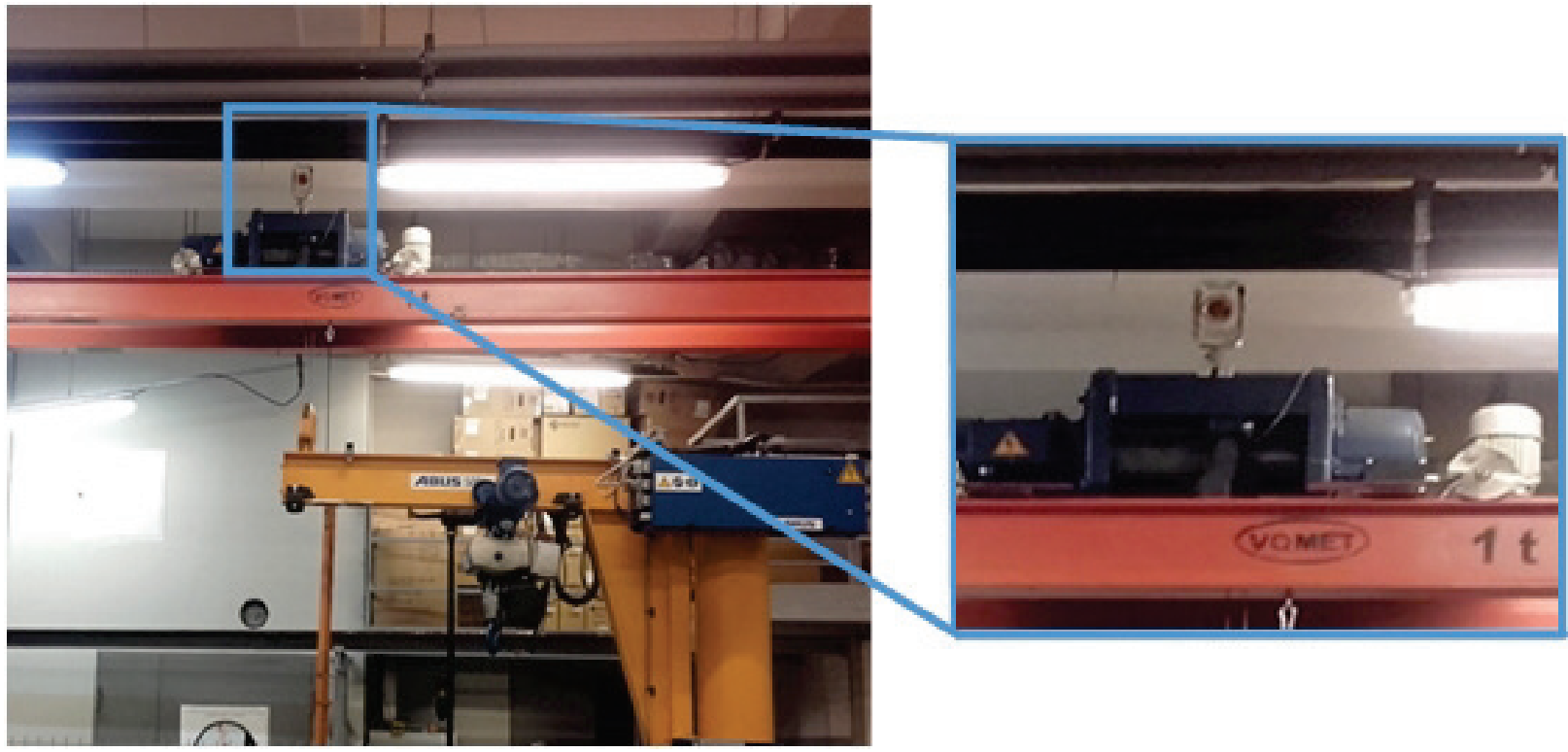

Fig. 4. The KTR1N PRO GPR1-SE prism attached to the crane trolley

The experiment was started from the travel of the crane trolley without load. In the tachymeter, the continuous measurement mode was involved; the measurement interval was set every $3 \mathrm{~s}$. The used geodetic device in continuous measurement mode works in such a way that after activating this function the instrument rangefinder goes into the "tracking mode" all the time sending a laser beam towards the target and calculating the distance to them. However, the target does not have to be a static object, it can move. The only condition for the proper observation is to keep the target (prism) in continuous visibility. The data which tachymeter calculated in real time mode is horizontal angle, vertical angle and distance to target. Through this, it is possible to calculate the $x y z$ coordinates of the each measured point. In the experiment, the first pass of the trolley was without the load but every next was increased by $200 \mathrm{~kg}$, until to obtain maximum deice capacity $(1000 \mathrm{~kg})$. The sets of the obtained results were presented in the Figs. 5-10. In the presented Figures (5-10), the dashed line shows the deflection of the girder under the weight of the crane bridge and the trolley. On each presented Figures in the obstinate axis were placed data related with the girder length given in "meters" value, while in the ordinate axis contain data related with the deflection given in $10^{-3} \mathrm{~m}$ value.

Generally, it was observed that the unloaded girder is deflected by a value close to $5 \mathrm{~mm}$ value. This deflection does not practically change when the girder has been loaded with a load of $10 \%$ of the nominal crane lifting capacity (Fig. 5). 


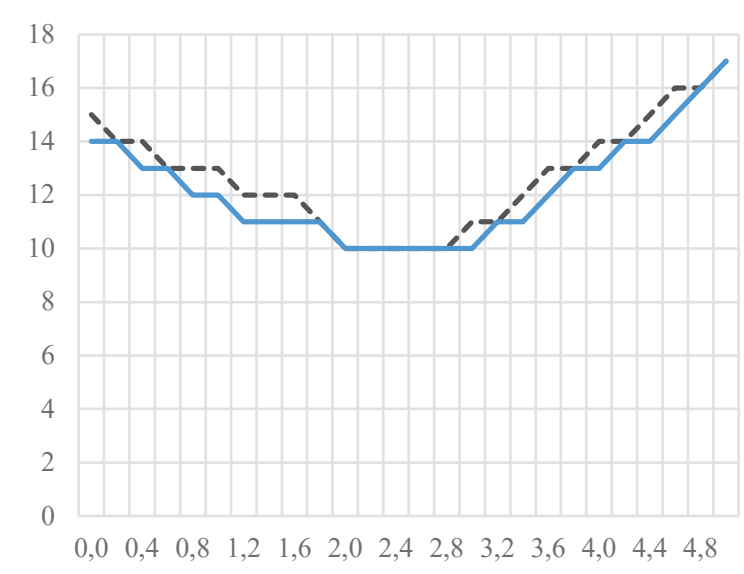

Fig. 5. Girder deflection under the impact of $10 \%$ of the nominal crane load

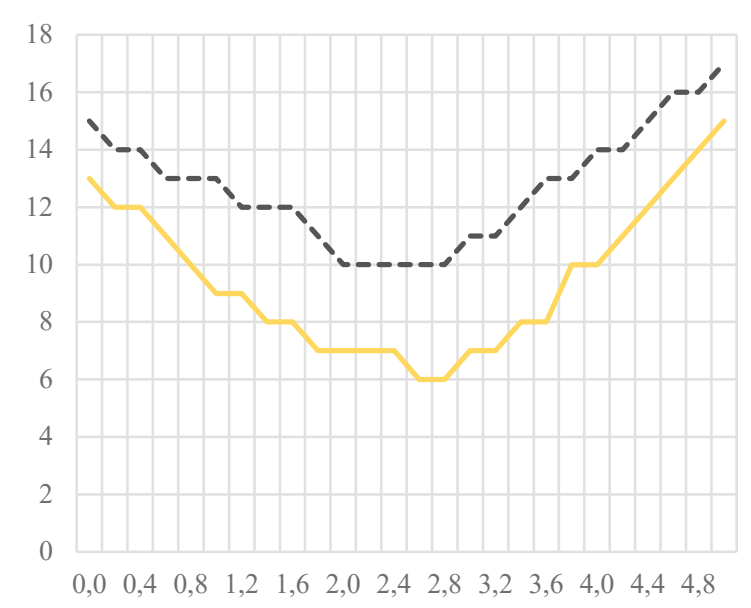

Fig. 7. Girder deflection under the impact of $40 \%$ of the nominal crane load

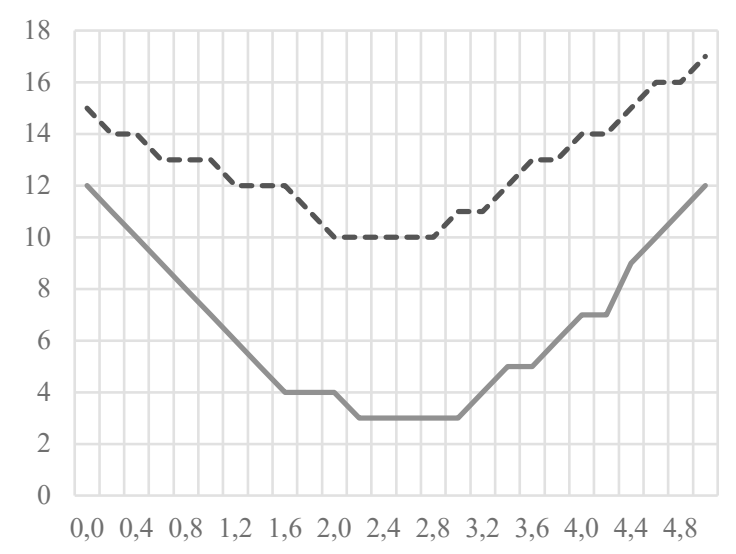

Fig. 9. Girder deflection under the impact of $80 \%$ of the nominal crane load

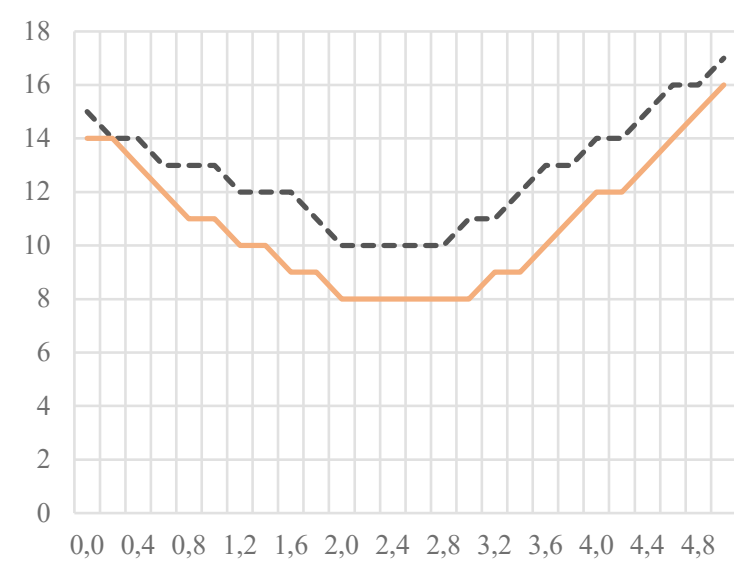

Fig. 6. Girder deflection under the impact of $20 \%$ of the nominal crane load

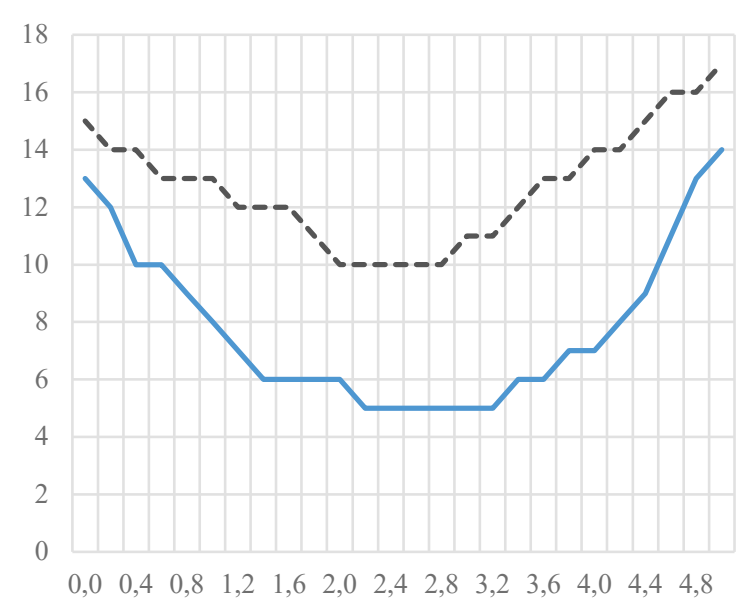

Fig. 8. Girder deflection under the impact of $60 \%$ of the nominal crane load

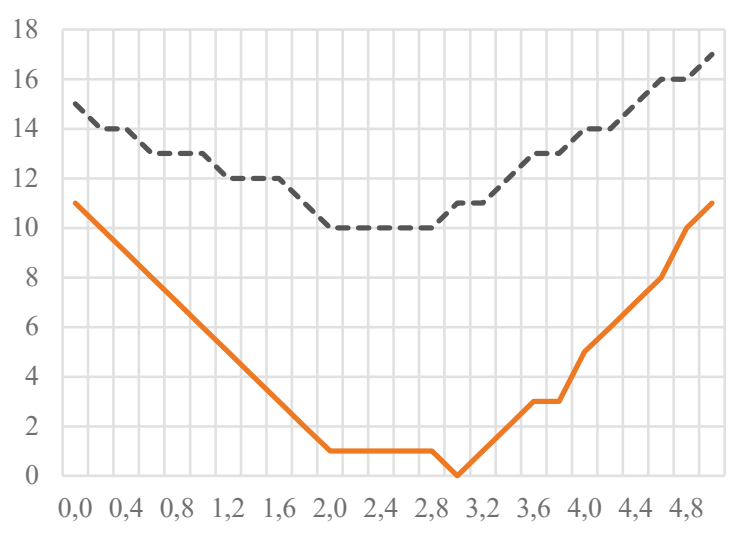

Fig. 10. Girder deflection under the impact of $100 \%$ of the nominal crane load

However, one more interesting thing was observed with using the achieved data. During the experiment the trolley move from the right rail to the left roadway crane rail (in the presented Figures it will be from the right-hand side of the to the left hand side). So, at the start of the trolley move each time the load was "swinging" - causes by dynamic forces impact. This is reflected 
in the chart line from the right rail to the centre of the crane bridge - the graph line is almost in each case an irregular shape, while in the second part of the passage, when the load has been stabilized, the graph's course is much softer. Summarizing each subsequent load increasing caused the bridge deflect by approximately by $2 \mathrm{~mm}$ on average. In this case, it can be assumed that each $100 \mathrm{~kg}$ of the load causes a deflection of $1 \mathrm{~mm}$ value (Figs. 6-10).

\section{Final remarks}

The continuous development of new measuring technologies in geodesy makes it possible to open new possibilities for testing large engineering constructions such a crane device. The presented experiment showed the usefulness of using a modern tachymetry device to the examine crane bridge deflection. It also has been shown that dynamic measurement can be a great support in solving various technical problems in cranes, which causes cannot be noticed during standard static tests. The presented measurement gives the possibility of not only tracking a moving load carrying by the crane, but also in real time supervising the trajectory of its all movement.

The conducted experiment also showed the advantage of using a robotic tachymetric station that allows measuring the deflection of the girder in a continuous way, as in the case of a standard geodetic methodology presented in Tab. 2. However, it should be noted that the presented method also has some imperfection. The used prism in which the laser beam was locked was located in the middle of the crane trolley construction (Fig. 4), which caused that the total length of the tested girder section has been reduced almost about $2 \mathrm{~m}$.

\section{References}

[1] Szpytko, J., Kształtowanie procesu eksploatacji środków transportu bliskiego, KrakówRadom 2004.

[2] Szpytko, J., Kocerba, A., Wybrane aspekty bezpieczeństwa i niezawodności rozproszonych środków transportu, Krakow-Radom 2008.

[3] Satoru, Y., Hiroki, U., Bridge Deflection Measurement Using Digital Image Correlation with Camera Movement Correction, Materials Transactions, Vol. 53, No. 2, pp. 285-290, 2012.

[4] Gocał, J., Geodezja inżynieryjno-przemysłowa, Cz. 3, Wydawnictwa AGH, Kraków 2010.

[5] Cosser, E., Roberts, G. W., Meng, X., Dodson, A. H., Measuring the dynamic deformation of bridges using a total station, Proceedings of the 11th FIG Symposium on Deformation Measurements, pp. 1-8, Santorini, Greece 2003.

[6] Margielewicz, J., Haniszewski, T., Gąska, D., Pypno, C., Badania Modelowe Mechanizmów Podnoszenia Suwnic, Komisja Transportu, 8 s., Polska Akademia Nauk, Katowice 2013.

[7] Hyla, P., Szpytko, J., The application of image analysis methods in selected issue solution dedicated for overhead travelling crane, Journal of KONES Powertrain and Transport, Vol. 21, No. 2, pp. 97-104, Warsaw 2014.

[8] Hyla, P., Szpytko, J., Telematics For The Purpose of Identifying The Conditions of Use of a Bridge Crane, Communications in Computer and Information Science, Vol. 897, pp. 480-492, Springer Nature Switzerland AG, 2018.

[9] Chodacki, J., Szpytko, J., Laboratorium urządzeń dźwigowych, Skrypt uczelniany AGH, Nr 1397, Wyd. AGH, Kraków 1994.

[10] Juzwa, K., Mercik, S., Wytyczne wykonania pomiarów suwnic i jezdni suwnicowych, Wydawnictwa przemysłu maszynowego „WEMA”, Warszawa 1982.

[11] PN-EN 15011:2011E, Dźwignice - Suwnice pomostowe i bramowe.

[12] PN-91/M-06503, Dźwignice - Grupy natężenia pracy dźwignic i ich mechanizmów.

[13] PN-93/M-45003/01, Dźwignice - Terminologia ogólna.

Manuscript received 04 June 2019; approved for printing 23 September 2019 